\title{
IMPROVING GROWTH PERFORMANCE AND CARCASS CHARACTERISTICS OF LAMBS AS A RESULT CARING MANAGEMENT VIA DIETARY YEAST SUPPLEMENTATION
}

\author{
H. A. Hamdon ${ }^{1}$ and M. M. Farghaly ${ }^{2}$
}

1- Department of Animal Production Department, Faculty of Agriculture, Assiut University, New Valley Branch, Egypt, 2- Department of Animal Production Department, Faculty of Agriculture, Assiut University, Egypt

\section{SUMMARY}

The objectives of this study were to evaluate the effect of levels yeast supplementation as a natural feed additive on growth performance, carcasses characteristic and some blood metabolites of growing Sohagi lambs. For this purpose, twenty-one Sohagi lambs $(27.00 \pm 0.75 \mathrm{~kg}$ body weight, 6 months old) were randomly assigned to three dietary treatments with seven lambs per treatment. The treatment groups were as follows:(G1) was kept as a control and fed a basal diet consisting of roughage and concentrate mixture. (G2) fed the basal diet supplemented with $0.5 \%$ of yeast culture (YC) (Saccharomyces cerevisiae) to the mixture, while (G3) received the same basal diet supplemented with $1 \%$ of YC. All animals were fed $60 \%$ of their requirements as concentrate mixture with crushed corn stover given ad libitum. The quantity of concentrate mixture was adjusted every month according to change in body weight. The results indicated that dietary supplementation of YC (0.5 or 1\%)did not significantly affect on body weight and daily gain. However, dry matter intake (DMI) of concentrate, roughage and total dry matter intake were significantly $(P<0.05)$ higher for lambs fed $Y C$ than control. Supplemented YC to lambs rations decreased significantly $(P<0.05)$ feed conversion ratio in comparison with the control treatment. Serum glucose and urea nitrogen were increased significantly $(P<0.05)$ in YC groups. However, the concentration of triglycerides and cholesterol decreased significantly $(p<0.05)$ when feeding YC diets. No differences were observed between treatments for hot carcass and carcass cuts with respect to flank, which recorded higher $(p<0.05)$ value for YC groups compared to control. Supplemented YC at level of $0.5 \%$ or $1 \%$ significantly $(P<0.05)$ increased dry matter and fat in meat compared with control groups. Water-holding capacity was significantly $(P<0.05)$ lower for YC groups than control. It was concluded that caring of animal management led to improvement productive performance of sheep, blood metabolites and carcass characteristics via dietary yeast supplementation. Also, YC may be more useful as a feed additive for growing lambs rations.

Keywords: lambs, growth performance, carcass characteristics, yeast culture

\section{INTRODUCTION}

In the recent years, the use of feed additives containing bacterial and yeast cultures (YC) as probiotics has been increased. These probiotics are live microbial feed supplements, which beneficially affect the host animal by improving its intestinal microbial balance, manipulate rumen fermentation and improve animal performance. (Nunes, 1994, Kassab and Mohammed, 2013, Ghazanfaret al., 2015 and Nour El-Din, 2015). Yeast cells contain different vitamins, enzymes and some unidentified cofactors that may improve the microbial activity and growth rate in rumen. Thus, it can be used as growth promoters to replace the widely used antibiotic and synthetic chemical feed supplements (Strzetelski, 1996).There is a widespread belief among dairy, beef and sheep producers that yeast supplementation is beneficial by enhancing dry matter intake (DMI) (Moallem et al., 2009), feed conversion efficiency, growth rate and nutrient digestibility (Wohlt et al., 1991).And at the same time prevent health disorders (Chaucheyras-Durand et al., 2008). Also, yeast culture has positive effects on blood contents resulting in improvement in health status of animals (Agazzi et al., 2014).

The effect of active dry yeast supplementation varies depending on biotic factors such as the strain of yeast, viability and animal type and its management, the physiological status and the level of production. Lynch and Martin (2002) compared live yeast cells and yeast culture and found that both Saccharomyces cerevisiae supplements had similar effects on the mixed ruminal microorganism fermentation. Yeasts are most efficient when animals are fed diets overloaded in energy, and thus easily fermented by rumen microorganisms, or diets poor in nutrient supply (Jouany et al., 1998).According to Kawas et al. (2007) there is a greater beneficial effect from yeast with forage-based diets versus high concentrate diets, in nutrition of lambs.

Meat with superior health benefits is obtained when lambs are fed rations supplemented with organic feed. Therefore, attempts are made to supplement lamb diets with natural stimulators (Collins and Ribson, 1999), including yeast (Saccharomyces cerevisiae), which has a wide spectrum of activity (Lyons, 2001). Milewski studies 
(2009) support the use of dried yeast (Saccharomyces cerevisiae) with prebiotic properties in lamb feeding; the administration of yeast mixed with concentrate stimulated the growth rate and muscle development in suckling lambs.

The present work was carried out to study lambs management by adding yeast culture at graded levels to Sohagi growinglambs rations on growth performance, carcasses characteristics and blood metabolites.

\section{MATERIALS AND METHODS}

The experiment was carried out at the Animal Production Research Farm, Faculty of Agriculture, Sohag University, Sohag, with jointly Department of Animal production, Faculty of Agriculture, Assiut University, Assiut, Egypt.

\section{Animals, rations and management:}

Twenty-one Sohagilambsof six month of age weighing $27.00 \pm 075 \mathrm{~kg}$ were used in this study. Animals were divided into three comparable groups of (six animals each) according to their average live body weight.Group one was kept as a control and fed a basal diet consisting of roughage and concentrate mixture. Group two fed the basal diet supplemented with $0.5 \%$ of yeast culture to concentrate mixture while group three received the same basal diet that supplemented with $1 \%$ of yeast culture to concentrate mixture according to Macedoet al. (2006) and Ozsoy et al. (2013). The yeast culture was added to concentrate mixture and mixed together per week. The contents of yeast culture used in this experiment according to manufactured by F.L. Emmert., Co. USA are illustrated in Table (1).

The control diet consists of concentrate mixture and crushed corn stover as roughage.The animal's requirements for crud protein (CP) and total digestible nutrients (TDN\& NE)were calculated according to NRC (1985). All animals of three groups were fed $60 \%$ of their requirements as concentrate mixture while crushed corn Stovergivenad libitum. The quantity of concentrate mixture was adjusted every month according to change in body weight. The animals were randomly allotted to experimental diets.

The chemical compositions of experimental diets are presentedin Table (2). Rations were offered twice a day and the feed residual were weighed daily through the experimental period and actual feed intake was calculated. Feed conversion ratio was calculated and expressed in terms of gram dry matter (DM) per gram body weight gain. Lambs were fed in groups(seven lambs per group) and it was kept together in one box (approximately 4 x $5 \mathrm{~m}$ ). The experimental periods consisted of two periods, 15days adjustment period followed by 150 days experimental period. Animals were weighed every week before morning feeding. Body weight was averaged to the nearest $0.5 \mathrm{~kg}$.Round the clock fresh and clean water was available to them. Lambs were de-wormed at the start of the experiment.

Table1. Contents of yeast culture (BGY-35, manufactured by F.L. Emmert. Co. USA) as fed*

\begin{tabular}{llllll}
\hline \multicolumn{2}{l}{ Vitamins, TDN \& NE } & Amino acids & \multicolumn{3}{l}{ Minerals } \\
\hline $\mathrm{E}$ & $36.80 \mathrm{IU} / \mathrm{kg}$ & Arginine & $1.83 \%$ & Calcium & $0.22 \%$ \\
Biotin & $2.44 \mathrm{mg} / \mathrm{kg}$ & Cystine & $0.58 \%$ & Phosphorus & $0.60 \%$ \\
Choline & $3401 \mathrm{mg} / \mathrm{kg}$ & Histidine & $0.85 \%$ & Sodium & $0.15 \%$ \\
Folic acid & $7.80 \mathrm{mg} / \mathrm{kg}$ & Isoleucine & $1.45 \%$ & Potassium & $0.20 \%$ \\
Niacin & $245.5 \mathrm{mg} / \mathrm{kg}$ & Leucine & $3.46 \%$ & Magnesium & $0.22 \%$ \\
Pantothenic acid & $59.2 \mathrm{mg} / \mathrm{kg}$ & Lysine & $1.63 \%$ & Manganese & $21.30 \mathrm{ppm}$ \\
Riboflavin & $18.25 \mathrm{mg} / \mathrm{kg}$ & Methionine & $0.62 \%$ & Iron & $184.05 \mathrm{ppm}$ \\
Thiamine & $46.2 \mathrm{mg} / \mathrm{kg}$ & Phenylalanine & $2.03 \%$ & Copper & $5.00 \mathrm{ppm}$ \\
Pyridoxine & $22 \mathrm{mg} / \mathrm{kg}$ & Threonine & $1.37 \%$ & Zinc & $75.00 \mathrm{ppm}$ \\
TDN & $70 \%$ & Tryptophan & $0.38 \%$ & Selenium & $1.00 \mathrm{ppm}$ \\
$\mathrm{NE}$ & $1.72 \mathrm{Mcal} / \mathrm{kg}$ & Valine & $2.05 \%$ & & - \\
\hline
\end{tabular}

*according to the manufactory benfleet

Table 2. Chemical composition of concentrate mixture and corn stover (\%, DMbasis)

\begin{tabular}{lcccc}
\hline Items & \multicolumn{3}{c}{ Concentration mixture } & Corn Stover \\
\cline { 2 - 4 } & Control & T1 & T2 & \\
\hline Dry matter(DM) & 90.82 & 89.76 & 89.24 & 91.87 \\
Crude protein(CP) & 19.07 & 21.54 & 21.69 & 6.63 \\
Crude fiber(CF) & 15.02 & 14.87 & 15.42 & 32.25 \\
Ether extract (EE) & 1.83 & 2.42 & 2.06 & 1.48 \\
Ash & 10.58 & 10.72 & 10.82 & 8.09 \\
Nitrogen free extract(NFE) & 53.50 & 50.46 & 50.00 & 51.55 \\
Organic matter(OM) & 89.42 & 89.28 & 89.18 & 91.91 \\
\hline
\end{tabular}

* The ingredients of concentrate feed mixture were: $20 \%$ Corticated cotton seed meal, $25 \%$ wheat bran, $37 \%$ yellow corn, $12 \%$ soybean meal, $3 \%$ vinasse, $2 \%$ limestone, $1 \%$ salt.T1: $0.5 \%$ dry yeast culture

T2: $1 \%$ dry yeast culture 


\section{Blood sampling:}

About $5 \mathrm{ml}$. of blood samples viajugular vein puncture were collected monthly after the morning feeding. Blood samples were immediately centrifuged at $3000 \mathrm{rpm}$ for $20 \mathrm{~min}$. and serum was stored at $-20{ }^{\circ} \mathrm{C}$ until analysis. Concentration of serum total protein (TP) albumin (AL), glucose, urea, triglycerides and cholesterol were determined by spectrophotometer (Unico, USA) using commercial test kits. Globulin (GL) concentration was obtained as the difference between the total protein and albumin concentrations.

\section{Carcass characteristics:}

At the end of the experiment period, three random animals from each group were slaughtered. Fasting body weight was recorded. Immediately after slaughtering hot carcass weight was recorded and weight of head, pelt, liver, lungs, heart, spleen, kidneys, kidney fat, omental fat, testes, lungs \&trachea and heart were recorded, these measurements and classifications of carcass were carried out according to Faten Abou-Ammou (1992). The carcasses were disjoined into the following wholesale cuts: legs, lion, rack, shoulders, neck, flank, brisket and tail as shown in Figure (1).Dressing percentage to fasting body weight was calculated. The carcass was cuts and weights of shoulder, leg, loin, rack, brisket, flank and longissimus dorsi muscle measurements were recorded. The 9, 10 and $11^{\text {th }}$ ribs cut of right sidesample were separate and frozen at $-20{ }^{\circ} \mathrm{C}$ to taken from longissimus dorsi muscle and after that untilchemical composition and physicochemical determine. The proximate chemical composition of meat was determined according to AOAC, (1990).The following physicochemical properties of meat were measured: $\mathrm{pH}-24 \mathrm{~h}$ postmortem by using $\mathrm{pH}$-meter and water-holding capacity - by the Grau-Hamm method (Oeckelet al., 1999).

Dressing $\%=\frac{\text { hot carcass weight }}{\text { fasting weight }} \times 100$

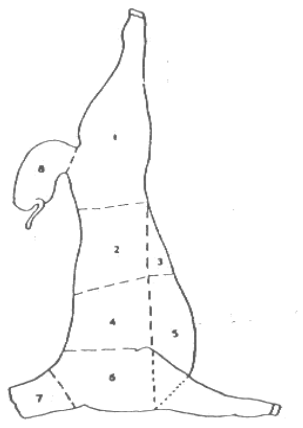

Leg

Lion

Flank

Rack

Brisket

Shoulder

Neck

Tail

Figure, 1. Carcass cuts

\section{Statistical analysis:}

Statistical analysis was carried out using general linear model (G.L.M) of S.A.S (2001) program, version 8.2. Differences between groups in growth performance, blood metabolites and carcass characteristics were evaluated by one-way ANOVA. The significance differences between treatments means were tested by Duncan Multiple Range Test (Steel and Torrie, 1980). The data were presented in mean \pm S.E.M and the level of significance was set at $\mathrm{P}<0.05$.

The utilized statistical model was:

$Y_{i j}=\mu+T_{i}+E_{i j}$

Where:

$\mathrm{Y}_{\mathrm{ij}}=$ the observation $\mathrm{ij}$.

$\mu=$ the overall mean.

$\mathrm{T}_{\mathrm{i}}=$ the effect due to treatment $\mathrm{i}$.

$\mathrm{E}_{\mathrm{ij}}=$ the experimental error.

\section{RESULTS AND DISCUSSION}

\section{Lambs growth performance:}

Results presented in Table (3) showed that the differences among all treatments in body weight, daily gain were not significant. This results agreement with this reported by Macedo et al, (2006) the found that yeast culture addition (Saccharomyce serevisiae) to lambs at rate $1 \%$ to diet had no significant effect on body weight and average daily gain as compared with control group. Similarly, Ozsoy et al. (2013) found that supplemented YC to goats at level of 1.5 to $3 \%$ did not significantly affect final live weight. In addition, were reported by Kumar and Ramana (2008) observed that the higher daily weight gain in animals fed diets supplemented with yeast culture. Ghazanfar et al. (2015) found that the average daily weight gain $(\mathrm{kg} / \mathrm{d})$ of heifers was higher $(\mathrm{P}<0.05)$ in supplemented $\mathrm{YC}$ group than control group. The same author attributed higher growth rate due to increased microbial protein flow escaping from the rumen and an enhanced supply of different amino acids entering the small intestine.

The dry matter intake of concentrate, roughages and total dry matter intake were significantly $(\mathrm{P}>0.05)$ higher for lambs fed supplement $0.5 \%$ and $1 \%$ of yeast culture than control (Table 3). This positive effect may result from manipulating rumen fermentation, stimulating cellulolytic in the rumen, improving fiber digestion, altering acetate to propionate ratios and increasing microbial protein flow to the duodenum (Bertin and Andrieu, 2005). The beneficial effects of yeast culture on fiber digestion may be partly responsible for the increase in dry matter intake often observed with yeast feeding (Jouany, 2006). Similarly, Abd El-Ghani (2004) reported that supplementation of 3 and $6 \mathrm{~g}$ yeast culture to Zarabi dairy goats diets, had positive effects on dry matter intake and feed conversion ratio. On contrary, Ghazanfar et al. (2015) found that the dry matter intake (DMI) was not different between heifers fed supplement yeast culture and control.

Regarding feed conversion ratio data presented in Table 2 showed that supplemented yeast culture at rate $0.5 \%$ and $1 \%$ to lambs rations decreased significantly $(\mathrm{P}<0.05)$ feed conversion ratio as 
compared with control (12.59 and 12.87 vs. 11.88, respectively). Lack effects of YC supplement on average daily gain reflected on fed conversion ratios that are consistent with literature. Titi et al. (2008) and Carrasco et al. (2012) reported no effects of YC and malate salt supplementation on average daily gain and fed conversion ratio in lambs, respectively. Also, Mikulec et al. (2010) demonstrated that 0.5 $\mathrm{g} /$ day and $1 \mathrm{~g} /$ day of live yeast cells supplementation to finishing lambs fed hay and high energy concentrate does not improve growth performance.

Table 3. Growth Performance $(M e a n \pm S E)$ of growing Sohagi lambs as affect by yeast culture supplementation

\begin{tabular}{lllll}
\hline Item & Control & T1 & T2 & P \\
\hline Initial weight $(\mathrm{kg})$ & $26.79 \pm 0.75$ & $27.00 \pm 0.69$ & $27.21 \pm 0.81$ & 0.923 \\
Final weight $(\mathrm{kg})$ & $44.43 \pm 1.73$ & $44.51 \pm 1.54$ & $44.41 \pm 1.49$ & 0.998 \\
BW gain $(\mathrm{kg})$ & $17.64 \pm 1.06$ & $17.51 \pm 1.19$ & $17.20 \pm 0.95$ & 0.956 \\
$\begin{array}{l}\text { Daily gain (g) } \\
\text { Feed Intake (FI, g/day) }\end{array}$ & $117.61 \pm 7.06$ & $116.76 \pm 7.97$ & $114.66 \pm 6.36$ & 0.956 \\
DMI of concentrate & $813.15^{\mathrm{b}} \pm 14.68$ & $863.42^{\mathrm{a}} \pm 15.15$ & $862.91^{\mathrm{a}} \pm 15.12$ & 0.025 \\
$\begin{array}{l}\text { DMI of corn Stover } \\
\text { Total DM intake }\end{array}$ & $548.34^{\mathrm{b}} \pm 8.35$ & $606.30^{\mathrm{ab}} \pm 7.92$ & $612.46^{\mathrm{a}} \pm 7.54$ & 0.032 \\
$\begin{array}{l}\text { Feed conversion } \\
\mathrm{kg} / \mathrm{kg} \text { gain) }\end{array}$ & $1397.49^{\mathrm{b}} \pm 17.60$ & $1469.72^{\mathrm{a}} \pm 19.09$ & $1475.38^{\mathrm{a}} \pm 19.24$ & 0.004 \\
\hline
\end{tabular}

Means within row bearing different superscripts differ significantly $(\mathrm{p}<0.05)$.

T1: $0.5 \%$ dry yeast culture

T2: $1 \%$ dry yeast culture

The reasons behind the different responses to yeast supplementation between our study and those of others may be associated with the variation in feedstuffs, feeding system, breeds and environmental conditions in each investigate. It is evident that yeast can have beneficial effects on performance under some circumstances, but there seems to be a considerable unexplained variability in response. This could be due to factors such as basal diet, viable cell numbers, and the amount of yeast supplemented, type of forage fed, and feeding strategy.

\section{Blood metabolites:}

The data of serum parameters are summarized in Table (4). No statistically significant differences were observed among all groups for blood proteins, albumin and globulin. Ozsoyet al. (2013) found that supplemented live $\mathrm{YC}$ at level of 1.5 to $4.5 \%$ to goatsnot affected on plasma levels of total proteins and its fractions at the same times, these rum glucose and urea nitrogen were significantly $(\mathrm{P}<0.05)$ increased in YC groups in compared with control. This result approved by Malekkhahi et al. (2015) they, found that plasma glucose concentration was higher $(\mathrm{p}<0.05)$ in lambs fed $\mathrm{YC}$ than in lambs fed the control. Finding similar results on the YC treatment indicated by Abo El-Nor and Kholif (1998) they reported that higher blood glucose and urea-N concentration in lactating buffaloes supplemented with YC. Also, Abdel Rahman et al. (2012) found that yeast culture supplementation significantly $(p<0.05)$ glucose concentrations, meanwhile it was not significantly affected blood total protein or globulin. On the contrary, Putnam et al, (1997) observed that serum urea nitrogen and plasma glucose were not affected by daily $10 \mathrm{~g}$ yeast culture addition to the diets of lactating cows. Generally, (Moallem et al., 2009) reported that yeast products might be more effective under stress rather than in the normal conditions.

Table 4. Some blood metabolites $(M e a n \pm S E)$ of growing Sohagi lambs as affect by yeast culture supplementation

\begin{tabular}{lllll}
\hline Item & Control & T1 & T2 & P \\
\hline Total protein $(\mathrm{g} / \mathrm{dL})$ & $7.67 \pm 0.13$ & $7.69 \pm 0.15$ & $7.59 \pm 0.13$ & 0.865 \\
Albumin $(\mathrm{g} / \mathrm{dL})$ & $3.76 \pm 0.19$ & $3.47 \pm 0.12$ & $3.58 \pm 0.15$ & 0.432 \\
Globulin $(\mathrm{g} / \mathrm{dL})$ & $3.91 \pm 0.21$ & $4.23 \pm 0.11$ & $4.01 \pm 0.06$ & 0.276 \\
Glucose $(\mathrm{mg} / \mathrm{dL})$ & $49.19 \mathrm{~b} \pm 0.57$ & $58.15 \mathrm{a} \pm 1.25$ & $58.73 \mathrm{a} \pm 1.26$ & 0.0001 \\
Urea, $(\mathrm{mg} / \mathrm{dL})$ & $20.32 \mathrm{~b} \pm 0.36$ & $22.96 \mathrm{a} \pm 0.56$ & $23.40 \mathrm{a} \pm 0.63$ & 0.0002 \\
Triglycerides $(\mathrm{mg} / \mathrm{dL})$ & $20.80 \mathrm{a} \pm 0.51$ & $14.51 \mathrm{~b} \pm 0.33$ & $13.76 \mathrm{~b} \pm 0.21$ & 0.001 \\
Cholesterol $(\mathrm{mg} / \mathrm{dL})$ & $61.50 \mathrm{a} \pm 0.69$ & $49.40 \mathrm{~b} \pm 0.61$ & $42.56 \mathrm{c} \pm 0.61$ & 0.0001 \\
\hline
\end{tabular}

Means within row bearing different superscripts differ significantly $(\mathrm{p}<0.05)$.

T1: $0.5 \%$ dry yeast culture $\quad$ T2: $1 \%$ e dry yeast culture

The average value of cholesterol and triglycerides for lambs fed diets supplemented with different level of $\mathrm{YC}$ were significantly $(\mathrm{P}<0.05)$ lower than those fed control(Table 4). The same result observed by Galip (2006) he reported that YC supplementation induced a significant reduction in serum triglyceride concentration $(0.05 \mathrm{~g} / \mathrm{l})$ compared to the control treatment $(0.117 \mathrm{~g} / \mathrm{l})$.Also, Kowalik et al. (2012) reported that the triacylglycerol and total cholesterol concentrations decreased significantly when live 
yeast cells were added to heifers feed comparing to heifers fed control diet or metabolites of yeast. The decrease in triacylglycerol and total cholesterol level in blood serum of lambs fed diet with YC (Saccharomyces cerevisiae) in the present study could be caused by some positive changes in rumen fermentation and population of microorganisms (Kowalik et al., 2012 and Malekkhahi et al., 2015).Moreover, the cell wall of yeast is a rich source of $\beta$-glucans. According to Nicolosi et. al.(1999) these polysaccharides reduce the total cholesterol of serum. Masek et al.(2008) found no influence of live yeast on triglyceride and total cholesterol concentration of blood.

\section{Carcass characteristics:}

Results presented in Table 5 showed that the differences in hot carcass and carcass components of lambs fed control or supplement yeast were not significant. At the same time, dressing percentage was significantly $(\mathrm{P}<0.05)$ higher in lambs fed control than lambs fed YC supplement (51.48 vs. 48.36 and 48.13 , respectively. Very little published literature is available concerning the effects of yeast supplementation on carcass characteristics. Kawas et al. (2007) showed that yeast had no effect on hot and chilled carcass weights, or dressing proportions of lambs fed a high grain finishing diet. Also, Mikulec et al. (2010) found that dressing percentage did not affected among lambs fed $0.5 \mathrm{~g} /$ day and $1 \mathrm{~g} /$ day of live yeast and control (52.49 and $51.97 v s$. 52.19) respectively. In contrary, Abdel Rahman (2010) found that higher dressing percentages for lambs from the control group than lambs fed on two doses direct microbial.

Table 5. Hot carcass, dressing \% and carcass cuts (Mean \pm SE) of growing Sohagi lambs as affect by yeast culture supplementation

\begin{tabular}{lcccc}
\hline Item (kg) & Control & T1 & T2 & P \\
\hline Slaughter weight, kg & $42.18 \pm 2.62$ & $43.61 \pm 1.89$ & $44.78 \pm 3.30$ & 0.795 \\
Hot carcass, kg & $21.73 \pm 1.51$ & $21.73 \pm 0.80$ & $21.57 \pm 1.60$ & 0.940 \\
Dressing percentage, \% & $51.48^{\mathrm{a}} \pm 0.44$ & $48.36^{\mathrm{b}} \pm 0.39$ & $48.13^{\mathrm{b}} \pm 0.18$ & 0.001 \\
Shoulder & $3.88 \pm 0.20$ & $3.67 \pm 0.15$ & $3.91 \pm 0.31$ & 0.758 \\
Legs & $6.93 \pm 0.43$ & $6.36 \pm 0.28$ & $6.20 \pm 0.53$ & 0.494 \\
Lion & $1.28 \pm 0.09$ & $1.43 \pm 0.07$ & $1.55 \pm 0.19$ & 0.399 \\
Neck & $1.81 \pm 0.06$ & $2.17 \pm 0.0 .29$ & $2.01 \pm 0.07$ & 0.401 \\
Rack & $4.97 \pm 0.39$ & $4.60 \pm 0.03$ & $4.74 \pm 0.40$ & 0.729 \\
Brisket & $0.666 \pm 0.08$ & $0.620 \pm 0.04$ & $0.557 \pm 0.09$ & 0.633 \\
Flank & $0.450^{\mathrm{b}} \pm 0.08$ & $0.800^{\mathrm{a}} \pm 0.04$ & $0.917^{\mathrm{a}} \pm 0.11$ & 0.020 \\
Longissimus dorsi muscle & $0.493 \pm 0.03$ & $0.517 \pm 0.03$ & $0.530 \pm 0.02$ & 0.628 \\
\hline Mea
\end{tabular}

Means within row bearing different superscripts differ significantly $(\mathrm{p}<0.05)$.

T1: $0.5 \%$ dry yeast culture T2: $1 \%$ e dry yeast culture

The results showed that there were no significantly $(\mathrm{P}<0.05)$ differences among all groups for carcass cuts except those of flank, it was significantly $(\mathrm{P}<0.05)$ higher by about $43.8 \%$ and $50.9 \%$ for lambs fed $0.5 \% \mathrm{YC}$ and $1 \% \mathrm{YC}$ than lambs fed control rations, respectively. Also, it could be noticed the lion and neck cuts were improved by about (10.5 and $16.6 \%)$ and (17.4 and $10 \%)$ for lambs fed $0.5 \% \mathrm{YC}$ and $1 \% \mathrm{YC}$ than lambs fed control rations respectively. Data in table (6) showed the weights of edible and non-edible parts of carcass likes head, pelt, liver, lungs, heart, spleen, kidneys, kidney fat, omental fat, testes, lungs \& trachea and heart did not differ significantly among all treatments.

Table 6. Edibleand non-edible parts $(\mathrm{Mean} \pm \mathrm{SE})$ as affect by yeast culture supplementation

\begin{tabular}{lllll}
\hline Item & Control & T1 & T2 & P \\
\hline Pelt, kg & $3.22 \pm 2.32$ & $4.37 \pm 0.37$ & $4.15 \pm 0.30$ & 0.114 \\
GI-Full, kg & $8.66 \pm 0.69$ & $9.97 \pm 0.14$ & $10.08 \pm 1.05$ & 0.375 \\
GI- Empty, kg & $4.92 \pm 0.32$ & $5.56 \pm 0.16$ & $4.92 \pm 0.57$ & 0.471 \\
Head, kg & $3.14 \pm 0.21$ & $3.02 \pm 0.16$ & $3.12 \pm 0.11$ & 0.859 \\
Feet, kg & $1.00 \pm 0.03$ & $0.96 \pm 0.01$ & $0.96 \pm 0.03$ & 0.440 \\
Kidney fat, kg & $0.04 \pm 0.02$ & $0.06 \pm 0.02$ & $0.07 \pm 0.03$ & 0.635 \\
Omental Fat, kg & $0.10 \pm 0.02$ & $0.20 \pm 0.05$ & $0.25 \pm 0.08$ & 0.265 \\
Tail, kg & $1.49 \pm 0.10$ & $1.40 \pm 022$ & $1.43 \pm 0.10$ & 0.984 \\
Liver, kg & $0.84 \pm 0.08$ & $0.75 \pm 0.05$ & $0.84 \pm 0.07$ & 0.481 \\
Kidney, kg & $0.11 \pm 0.01$ & $0.127 \pm 0.02$ & $0.11 \pm 0.01$ & 0.489 \\
Testes, kg & $0.17^{\mathrm{b}} \pm 0.04$ & $0.26^{\mathrm{ab}} \pm 0.05$ & $0.37^{\mathrm{a}} \pm 0.02$ & 0.025 \\
Spleen, kg & $0.24 \pm 0.18$ & $0.08 \pm 0.01$ & $0.11 \pm 0.01$ & 0.554 \\
Heart, kg & $0.26 \pm 0.02$ & $0.20 \pm 0.02$ & $0.21 \pm 0.01$ & 0.091 \\
Lungs and Trachea & $0.61 \pm 0.02$ & $0.65 \pm 0.05$ & $0.56 \pm 0.03$ & 0.288 \\
\hline
\end{tabular}

Means within row bearing different superscripts differ significantly $(\mathrm{p}<0.05)$.

$\begin{array}{ll}\text { T1: } 0.5 \% \text { dry yeast culture } & \text { T2: } 1 \% \text { e dry yeast culture }\end{array}$ 
The data of chemical composition and physic chemical properties of lamb's meat are summarized in Table (7).Supplemented YC at level of $0.5 \%$ and $1 \%$ to concentrate mixture increased significantly $(\mathrm{P}<0.05)$ dry matter and fat in meat as compared with control groups. However, no significant differences were observed in protein, ash and $\mathrm{pH}$ between supplemented treatments and control. The increase of fat content could be considered desirable as it resulted in positive changes in the fatty acid composition of intramuscular fat. Similarly, Milewski and Zaleska (2011) and Abdelrahman
(2010) reported that yeast supplement contributed to an increase in the dry matter and fat content in meat. Also, Titi et al. (2008) reported significant changes in the chemical composition of meat (an increase in fat content and a decrease in protein content) from lambs fed diets supplemented with live yeast cultures. In the present results, water-holding capacity was lower significantly $(\mathrm{P}<0.05)$ in $\mathrm{YC}$ supplement than control. A lower water-holding capacity is usually correlated with a lighter colour of meat (Milewski and Zaleska, 2011).

Table 7. Chemical composition and physicochemical properties (Mean \pm SE) of longissimus dorsi muscle lambs as affected by yeast culture supplementation

\begin{tabular}{lllll}
\hline Item & Control & T1 & T2 & P \\
\hline Dry matter $(\%)$ & $24.78 \mathrm{~b} \pm 0.16$ & $26.00 \mathrm{a} \pm 0.07$ & $26.21 \mathrm{a} \pm 0.29$ & 0.001 \\
Protein $(\%)$ & $20.67 \pm 0.13$ & $20.56 \pm 0.09$ & $20.58 \pm 0.17$ & 0.830 \\
Fat $(\%)$ & $2.47 \mathrm{~b} \pm 0.05$ & $2.87 \mathrm{a} \pm 0.05$ & $2.89 \mathrm{a} \pm 0.08$ & 0.002 \\
Ash $(\%)$ & $1.13 \pm 0.05$ & $1.11 \pm 0.05$ & $1.13 \pm 0.01$ & 0.954 \\
pH & $5.46 \pm 0.05$ & $5.77 \pm 0.04$ & $5.76 \pm 0.06$ & 0.215 \\
Water-holding capacity $(\mathrm{cm} 2)$ & $18.93 \mathrm{a} \pm 0.13$ & $17.21 \mathrm{~b} \pm 0.15$ & $16.92 \mathrm{~b} \pm 0.23$ & 0.001 \\
\hline
\end{tabular}

Means within row bearing different superscripts differ significantly $(\mathrm{p}<0.05)$.

$\begin{array}{ll}\text { T1: } 0.5 \% \text { yeast culture } & \text { T2: } 1 \% \text { e yeast culture }\end{array}$

\section{COUNCLSION}

It was concluded that caring of animal management led to improvement productive performance, blood metabolites and carcass characteristics of sheep via dietary yeast supplementation at level 0.5 and $1 \%$. Results obtained positive effects of live yeast culture on feed intake and serum glucose. Moreover, supplementation of yeast decreased concentration of triacylglycerol and total cholesterol of blood serum. Supplementation of diet for lambs with dried yeast (Saccharomyces cerevisiae), had a significant effect ondry matter and fat content of meat. However, the differences between yeast treatments $(0.5$ and $1 \%)$ for most parameters not significant.

\section{REFERENCES}

Abd El-Ghani A. A., 2004. Influence of diet supplementation with yeast culture (Saccharomyces cerevisiae) on performance of Zaraibi goats. Small Ruminant Research 52(3): 223-229.

Abdel-Rahman M. M., 2010.Effect of direct- fed microbial (DFM) supplements on general performance of newborn Awassi lambs. Egyptian Journal of Sheep\& Goat Science, 5(1): 249-266.

Abdel-Rahman, H; G.A. Baraghit; A.A. Abu El-Ella; S.S. Omar; Faten F. Abo Ammo and O.F. Komonna, 2012. Physiological responses of sheep to diet supplementation with yeast culture. Egypt J. of Sheep \& Goats Sciences, 7 (1): 27-38.

Abo El-Nor, S. A. H.,M. A.Kholif, 1998.Effect of supplementation of live yeast culture in the diet on the productive performance of lactating buffaloes. Milchwissenschaft 53, 663-666.

Agazzi, A., E. Tirloni, S. Stella, S. Maroccolo, B. Ripamonti, C. Bersani, J. M. Caputo, V. Dellorto, N. Rota, and G. Savoini, 2014.Effects of speciesspecific probiotic addition to milk replacer on calf health and performance during the first month of life. Annals of Animal Science, 14 (1): 101-115

AOAC, 1990, Association of Official Analytical Chemists, Official Methods of Analysis. $15^{\text {th }}$ Edition. Washington, DC

Bertin, G and S. Andrieu,2005.Effect of yeast culture (Yea-Sacc®1026) supplementation on performance of high-producing dairy cows. The $21^{\text {st }} \quad$ Annual Symposiumon "Nutritional Biotechnology in the Feed and Food Industries" May 23-25, Lexington, KY, USA, Supplement (1),pp126.

Carrasco, C.,P. Medel, A. Fuentetaja, M. D. Carro, 2012. Effect of malate from (acidor disodium/ calcium salt) supplementation on performance, ruminal parameters and blood metabolites of feedlot cattle. Animal Feed Science and Technology, 176(1): 140-149.

Chaucheyras-DurandF., Walker, N. D., A.Bach, 2008. Effects of active dry yeasts on the rumen microbial ecosystem: past, present and future. Animal Feed Science and Technology, 145(1):526.

Collins M.D., G.R. Ribson, 1999. Probiotics, prebiotics and symbiotics: approaches for modulating the microbial ecology of the gut. The American Journal of Clinical Nutrition, 69(5): 1052-1057. 
Faten Abou-Ammou, M. 1992. Effect of ration and breed on the distribution of fat in sheep. Ph.D. Thesis, Fac. of Agric., Ain Shams Univ., Egypt.

Galip, N., 2006.Effect of supplemental yeast culture on ruminal protozoa and blood parameters in rams. Revue de Médecine Vétérinaire, 157: 519524.

Ghazanfar S., M. I. Anjum1, A. Azim and I. Ahmed ., 2015. Effects of dietary supplementation of Yeast (Saccharomyces cerevisiae) culture on growth performance, blood parameters, nutrient digestibility and fecal flora of dairy heifers. The Journal of Animal \& Plant Sciences, 25(1): 2015, Page: 53-59

Jouany, J. P., F. Mathieu, J. Senaud, J. Bohatier, G. Bertin, M. Mercier, 1998. The effects of Saccharomyces cerevisiaeandAspergilusoryzaeon the digestion of the cell wall fraction of a mixed diet in defaunated and refaunated sheep rumen.Reproduction, nutrition, development,38(4): 401-416.

Jouany, J.P., 2006. Optimizing rumen functions in the close-up transition period and early lactation to drive dry matter intake and energy balance in cows. Animal Reproductive Science.96: 250-264.

Kassab A. Y. and A. A. Mohammed, 2013. Effects of dietary live dried yeast on some physiological responses and productive performances in Sohagi ewes. Egyptian Journal Nutrition and Feeds, 16 (2): $215-225$.

Kawas, J. R., R. Garcia-Castillo, F. Garza-Cazares, H. Fimbres-Durazo, E. Olivares-Saenz, G. Hernandez-Vidal, C. D. Lu, 2007. Effects of sodium bicarbonate and yeast on productive performance and carcass characteristics of lightweight lambs fed finishing diets. Small Ruminant Research, 67, 157-163.

Kowalik, B.,Skomial, J.,Pajak, J. J.,Taciak, M.,Majewska, M.,Belzecki, G., 2012. Population of ciliates, rumen fermentation indicators and biochemical parameters of blood serum in heifers fed diets supplemented with yeast (Saccharomyces cerevisiae) preparation. Animal Science Papers and Reports, 30, 329-338.

Kumar, M. K., and D. B. V. Ramana., 2008; Effect of supplementation of yeast culture to calves fed with complete diet. India Veterinary Journal; 85: 667-669.

Lynch, H. A., S. A. Martin, 2002. Effects of Saccharomyces cerevisiaeculture and Saccharomyces cerevisiaelive cells on in vitro mixed ruminal microorganism fermentation. Journal DairyScience, 85, 2603-2608.

Lyons P., 2001.A time for answer: solution for the 2001 feed industry.Science and Technology in the Feed Industry.Proceedings of Alltech's $17^{\text {th }}$ Annual Symposium. Nottingham University Press, pp. 1-23

Macedo, R.,V. Arredondo, and J. Beauregard, 2006. Influence of yeast culture on productive performance of intensively fattened Pelibuey lambs in Colima, México. Avances en Investigación Agropecuaria, 10(3): 59-67.

Malekkhahi M., A. M. Tahmasbi, A. A. Naserian, M. Danesh Mesgaran, J. L. Kleen and A. A. Parand, 2015. Effects of essential oils, yeast culture and malate on rumen fermentation, blood metabolites, growth performance and nutrient digestibility of Baluchi lambs fed highconcentrate diets. Journal of Animal Physiology and Animal Nutrition, 99 (2): 221-229.

Masek T.,Z. Mikulec, H. Valpotic,L. Kusce, N. Mikulec, N. Antunac, 2008. The influence of live cells (Saccharomyces cerevisiae)on the performance of grazing dairy sheep in late lactation. Veterinarski Arhiv, 78(2): 95-104

Mikulec1, Z., T. Masek, B. Habrun, H. Valpotic, 2010. The influence of Saccharomyces cerevisiae supplementation to the diet of fattening lambs on growth performance and rumen bacterial number. Vetrinarski Arhiv, 80 (6), 695-703.

MilewskiS.and B. Zaleska, 2011.The effect of dietary supplementation with Saccharomyces cerevisiaedried yeast on lambs meat quality. Journal of Animal and Feed Sciences, 20, 537545

Milewski S., 2009. Effect of yeast preparations Saccharomyces cerevisiae on meat performance traits and blood hematological indicies in sucking lambs.Medycynaweterynaryajna, 65(1): 51-54

Moallem, U., H. Lehrer, L. Livshitz, M. Zachut and S. Yakoby, 2009.The effects of live yeast supplementation to dairy cows during the hot season on production, feed efficiencyanddigestibility.JournalDairyScience, 92:343-351.

Nicolosi R., S.J Bell., Bistrian B. R.,I. Greenberg, R. A.Forse., Blackburn G. L, 1999. Plasma lipid changes after supplementation with $\beta$-glucan fiber from yeast. American Journal of Clinical Nutrition 70,208-212.

NourEl-din A.N.M., 2015. Milk production and some blood metabolite responses to yeast supplementation in early lactating holstein dairy cows. Egyptian Journal Animal Production, 52(1):11-17

N.R.C, 1981.Nutrient Requirements of sheep. National Academy of Science. National Research Council, Washington, DC, U.S.A.

Nunes, C.S., 1994 "Microbial Probiotics and Their Utilization in Husbandry" Rev. Portuguesa de Cie. Vet., 89 (512): 166-174.

Oeckel M.J. van, N. Warnants,V.Ch. Boucqueé, 1999.Comparison of different methods for measuring water holding capacity and juiciness of pork versus on-line screening methods. Meat Science.51, 313-320

Ozsoy, B., S. Yalcin, Z. Erdogan, Z. Cantekin, T. Aksu, 2013. Effects of dietary live yeast culture on fattening performance on some blood and rumen fluid parameters in goats. Revue de Médecine Vétérinaire, 164(5): 263-271 
Putnam, D. E., C. G. Schwab, M. T. Socha, N. L. Whitestone, N. A. Kierstead and B. D. Gaithwaite, 1997. Effect of yeast culture in the diets of early lactation dairy cows on ruminal fermentation and passage of nitrogen fractions and amino acidsto the small intestine. Journal of Dairy Science, 80:374-384.

SAS, 2001.Statview for Windows, Version 8.2.SASInstitute, Cary, NC, USA.

Steel, R.G. and J.H. Torrie, 1980."principles and Procedures of Statistics".A Biometrical Approach $\left(2^{\text {nd }}\right.$ Ed) Mc Grow- Hill Book Co., New York.
Strzetelski, J., 1996. "Modern Principles and Methods of Fattened Cattle Nutrition.'Inst. Zootech. Inf., 34, 45-65.

Titi, H. H.,K.Dmour,A. Y. Abdullah,2008. Growth performance and carcass characteristics of Awassi lambs and Shami goat kids fed yeast culture in their finishing diet. Animal Feed Science and Technology, 142(1): 33-43.

Wohlt, J.E., A.D. Finkelstein and C.H. Ghung, 1991. Yeast culture to improve intake, nutrient digestibility and performance by dairy cattle during early lactation. Journal of Dairy Science. 74(4): 1395-1400

تحسين آداء النمو وخصائص الأبيحة فى الحملان نتيجة لرعايتها باضافة الخميرة حاتم عبد القادر حمدون'، محسن محمد فرغلى'

ا ـ قسم الإنتاج الحيوانى، كلية الزراعة (فرع الوادى الجبلد)، جامعة اسيوط، الذارجة، مصر، ب ـ قسم الإنتاج الحيوانى،كلية الزيراعة، جامعة

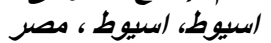

الهدف من الدراسة تحسين آداء نمو وخصائص الذبيحة للحملان النامية من خلال نظام رعاية الحملان باضافة الخميرة كأحد الاضافات

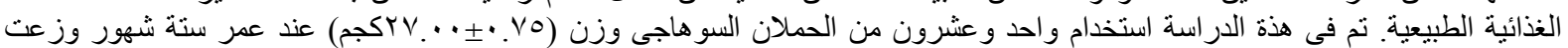

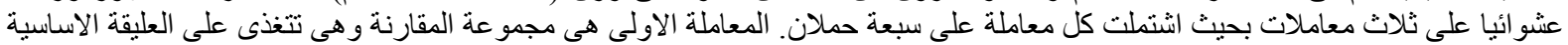

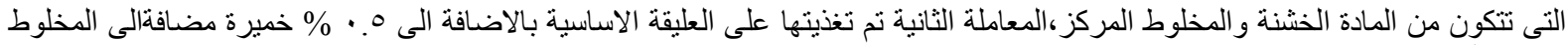

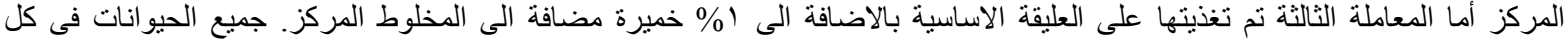

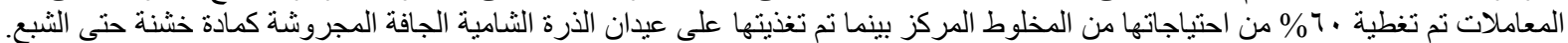

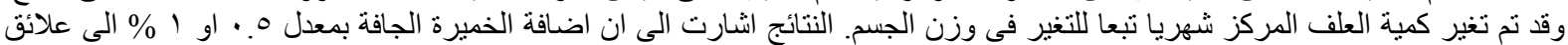

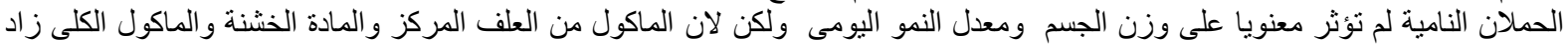

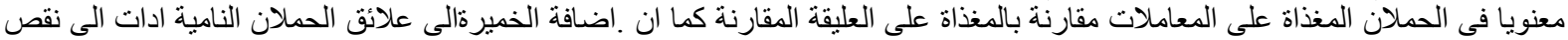

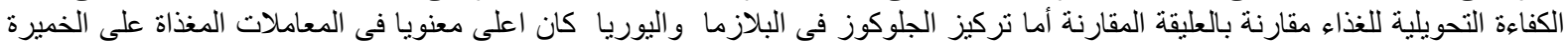

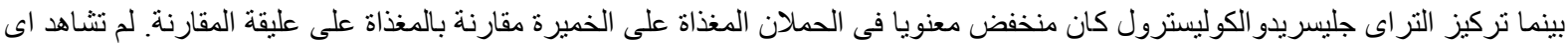

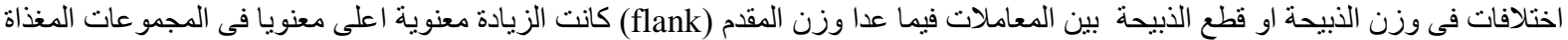

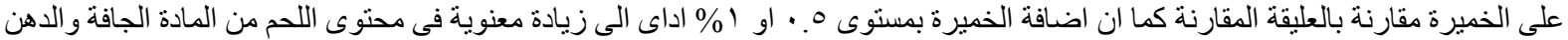

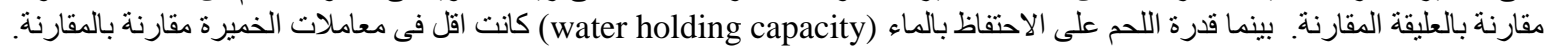

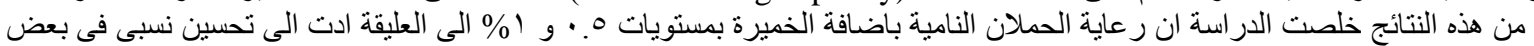

